\title{
PEMANFAATAN SAMPAH PLASTIK UNTUK KERAJINAN RUMAH TANGGA TAMAN BELAJAR KREATIF MEKAR SARI
}

\author{
Paeno $^{1 *}, \operatorname{Kasmad}^{2}$, Denok Sunarsi $^{3}$, Ali Maddinsyah ${ }^{4}$, \\ Dede Supiyan $^{5}$ \\ 1,2,3,4,5 Program Studi Manajemen, Fakultas Ekonomi, Universitas Pamulang \\ Jl. Surya Kencana No.1, Pamulang Barat, Kec. Pamulang \\ Kota Tangerang Selatan, Banten 15417 \\ *Penulis Korespodensi: dosen01362@unpam.ac.id
}

\begin{abstract}
ABSTRAK
Tujuan diselenggarakannya kegiatan Pengabdian Kepada Masyarakat ini adalah untuk Pemanfaatan Sampah Plastik Untuk Kerajinan Rumah Tangga Taman Belajar Kreatif Mekarsari yang sesuai dengan perkembangan jaman yang aktual dan terkini. Selain itu dapat menggerakkan para anggota Pengurus untuk dapat mengedukasi lingkungan dan menjadi program di era milenial seperti saat ini. Dengan menggunakan diskusi kelompok, penyuluhan ini mengedukasi pengelola Taman Belajar Kreatif Mekarsari akan pemanfaatan limbah plastic (bungkus kopi instan). Hasil kegiatan adalah meningkatkan motivasi berwirausaha oleh narasumber, kegiatan demonstrasi pembuatan produk usaha berbahan dasar sampah plastik serta kegiatan penyuluhan mengenai bagaimana hasil produk tersebut dibuat sebagai kegiatan wirausaha
\end{abstract}

Kata Kunci :Sampah Plastik, Kerajian Rumah Tangga

\begin{abstract}
The purpose of this Community Service activity is for the Utilization of Plastic Waste for Household Crafts Mekarsari Creative Learning Park in accordance with the development of the current and current era. In addition it can move the members of the Board to be able to educate the environment and become a program in the millennial era as it is today. By using group discussions, the education program educates the managers of Mekarsari Creative Learning Park on the use of plastic waste (instant coffee packs). The results of the activities are to increase entrepreneurship motivation by the resource persons, demonstration activities for the manufacture of products made from plastic waste and counseling activities on how the results of the products are made as entrepreneurial activities.
\end{abstract}

Keywords: Plastic Waste, Household Crafts

\section{PENDAHULUAN}

Manajemen merupakan salah satu program studi di Universitas Pamulang. Program studi ini memiliki andil dalam mencetak lulusan yang berkarakter serta 
Paeno, dkk

mampu bersaing di dalam dunia kerja, serta dapat berperan bagi pembangunan. Pengabdian kepada masyarakat adalah bentuk Kegiatan pengabdian masyarakat merupakan salah satu Tri Dharma Perguruan Tinggi Selain Pendidikan dan Penelitian, sesuai undang-Undang RI Nomor 20 Tahun 2003 tentang Sistem Pendidikan Nasional, pada Pasal 20 ayat 2 dinyatakan: "Perguruan Tinggi berkewajiban menyelenggarakan pendidikan, penelitian dan pengabdian masyarakat". Pada Pasal 24 ayat 2 disebutkan:'Perguruan tinggi memiliki otonomi untuk mengelola sendiri lembaganya sebagai pusat penyelenggaraan pendidikan tinggi, penelitian ilmiah, dan pengabdian masyarakat".

Pengabdian kepada masyarakat merupakan pelaksanaan pengamalan ilmu pengetahuan, teknologi dan seni budaya langsung pada masyarakat secara kelembagaan melalui metodologi ilmiah sebagai penyebaran Tri Dharma Perguruan Tinggi serta tanggung jawab yang luhur dalam usaha mengembangkan kemampuan masyarakat, sehingga dapat mempercepat laju pertumbuhan tercapainya tujuan pembangunan nasional.

Kantong plastik yang sudah dibeli ternyata pada akhirnya tetap dibuang dan menjadi sampah (Purwaningrum, 2016b). Bermula dari inisiatif para pecinta lingkungan mencoba melihat ini sebagai permasalahan sekaligus peluang (Nasution, Rahmalina, Sulaksono, \& Doaly, 2019). Mereka berinisiatif untuk mendaurulang sampah kantong plastik itu jadi sesuatu yang berguna. Taman Belajar Kreatif Mekarsari yang berisi anak-anak muda dapat mengembangkannya menjadi salah satu kegiatan belajar kreatif sekaligus berupaya untuk tidak menjadi salah satu penyumbang sampah yang sangat mengganggu lingkungan serta menciptakan solusi untuk permasalahan sampah di lingkungan (Qodriyatun, 2018). Pelatihan daur ulang tersebut berawal dari keresahan yang melihat banyak sampah plastik bekas bungkus kopi dan minuman instan lainnya yang hanya dibuang begitu saja.

Dari kondisi tersebut, mereka melihat adanya peluang untuk memanfaatkannya menjadi sesuatu yang bermanfaat. Pelaksanaan kegiatan dimulai dengan penyampaian materi secara langsung di depan peserta pelatihan. Kemudian dilanjutkan dengan praktik daur ulang sampah plastik menjadi berbagai macam kerajinan tangan dengan pendampingan tim ahli. kegiatan tersebut bertujuan untuk membantu mengurangi keberadaan sampah plastik di lingkungan. Selain itu juga dapat digunakan untuk meningkatkan ekonomi dan kreativitas masyarakat setempat. Diharapkan dengan adanya program ini, Taman Belajar Kreatif Mekarsari dan juga masyarakat di sini bisa melihat dan mengambil peluang dengan memanfaatkan bungkus plastik bekas kopi menjadi tas dan dompet atau perlengkapan rumah tangga. Sehingga nantinya akan mampu untuk membantu meningkatkan perekonomian mereka.

Program pengabdian kepada masyarakat merupakan salah satu program yang wajib dilaksanakan, baik oleh dosen maupun oleh mahasiswa, dengan berlandaskan pada prinsip-prinsip: motivasi pemenuhan kompetensi akademik, jiwa kewirausahaan (entrepreneurship), dan profesional, sehingga dapat menghasilkan program pengabdian kepada masyarakat yang bermutu, relevan, dan sinergis dalam meningkatkan pemberdayaan masyarakat. 


\section{METODE PELAKSANAAN}

Dengan menggunakan diskusi kelompok, penyuluhan ini mengedukasi pengelola Taman Belajar Kreatif Mekarsari akan pemanfaatan limbah plastic (bungkus kopi instan)

Akhir-akhir ini berita mengenai limbah plastik semakin mengkhawatirkan. Pasalnya limbah plastik ini bukan hanya ada di daratan saja, melainkan di lautan.

Namun tak semua yang berbahan plastik harus berakhir menjadi limbah. Pasalnya ada pula yang menggunakan plastik sebagai bahan kerajinan dan juga meningkatkan kreativitas. Salah satu yang sering digunakan ialah bungkus kopi. Bungkus kopi sendiri cukup sering dikreasikan menjadi berbagai hal seperti dompet maupun tas, terutama oleh para ibu-ibu pelaku UKM.

Tentu saja sebelum memulai untuk membuat tas dari bungkus kopi memerlukan alat dan juga bahan pendukung lainnya. Cara membuat tas dari bungkus kopi yang pertama ialah menentukan seberapa banyak bahan yang dibutuhkan.

Tentu saja untuk mengetahuinya, perlu memperhitungkan ukuran tas yang akan dibuat. Semakin besar tas yang akandibuat, maka bahan utama yang dibutuhkan pun semakin banyak. Berikut ini beberapa alat dan juga bahan yang perlu disiapkan.

1. Bungkus kopi instan. Tentu saja untuk cara membuat tas dari bungkus kopi bahan utama yang diperlukan ialah bungkus kopi instan. Jika ingin membuat tas berukuran kecil, paling tidak akan memerlukan kurang lebih 100 bungkus. Namun tentu saja banyaknya bungkus kopi yang dibutuhkan tergantung dari model dan juga ukurannya.

2. Gunting. Dalam cara membuat tas dari bungkus kopi memerlukan gunting. Selain digunakan untuk memotong bungkus kopi menjadi beberpa bagian, gunting ini pun digunakan untuk merapikan tas jika terdapat benag atau bungkus kopi yang melebihi ukuran.

3. Penggaris. Seperti sebelumnya dijelaskan, sebelum memulai membuat sebuh tas dari bungkus kopi, kamu harus mengukur terlebih dahulu seberapa besar tas yang akan kamu buat. Selain itu, penggaris ini digunakan untuk memotong bungkus kopi agar ukuran potongan sama rata.

4. Jarum dan benang. Benang dan juga jarum nantinya berguna untuk menyatukan bungkus kopi satu dengan yang lainnya.

5. Kain furing. Jika tidak memiliki kain furing, bisa menggantinya dengan kain polos. Kain ini nantinya akan digunakan sebagai alas bagian dalam tas dari bungkus kopi ini.

6. Risleting. bisa menggunakan risleting ukuran standar untuk tas daur ulang. Penggunaan risleting pun bisa mempermudah saat memakai tas dari bungkus kopi.

\section{HASIL DAN PEMBAHASAN}

Pengelolaan sampah melalui pendekatan sumber memungkinkan pengelolaan sampah secara terpadu mulai dari hulu sampai ke hilir (Purwaningrum, 2016a). Partisipasi masyarakat merupakan aspek terpenting dalam kegiatan pengelolaan sampah terpadu ini (Sulistiyorini, Darwis, \& Gutama, 2016).Partisipasi merupakan suatu keterlibatan masyarakat untuk berperan secara aktif dalam suatu program yang 
Paeno, dkk

diusulkan.Partisipasi masyarakat tidak dapat dipaksakan, dan memerlukan waktu dan usaha yang berkelanjutan . Partisipasi masyarakat akan meningkat apabila masyarakat mengetahui nilai lebih dan keuntungan-keuntungan yang diperolah bagi individu mau pun lingkungan mereka sendiri jika melakukan pengelolaan sampah secara mandiri.

Suatu program pengelolaan kebersihan lingkungan, khususnya sampah tidak akan berhasil dengan baik bila hanya mengandalkan peran pemerintah. Pengenalan dan penerapan prinsip 3R (Reduce, Reuse, Recycle) atau pengurangan, penggunaan kembali dan mendaur ulang sampah, merupakan salah satu cara pendekatan sumber dalam pengelolaan sampah (Kementerian Pekerjaan Umum, 2010) . Dengan konsep ini masyarakat tidak hanya membuang sampah tapi sekaligus memanfaatkannya dan dapat mempunyai nilai tambah secara ekonomi.Sudah saatnya masyarakat mengubah paradigma sampah dari barang yang tidak berguna menjadi sesuatu yang bernilai ekonomi dan dapat dimanfaatkan.Pengelolaan sampah yang paling sederhana seperti memisahkan sampah organik dan anorganik di masyarakat merupakan kunci awal penerapan konsep 3R.

Pengenalan dan penerapan prinsip 3R (Reduce, Reuse, Recycle) atau pengurangan, penggunaan kembali dan mendaur ulang sampah, merupakan salah satu cara pendekatan sumber dalam pengelolaan sampah. Dengan konsep ini masyarakat tidak hanya membuang sampah tapi sekaligus memanfaatkannya dan dapat mempunyai nilai tambah secara ekonomi (Purwanto, Fatimah, \& Partono, 2013).Pengurangan sampah plastik menjadi hal yang penting karena sebagian besar wadah yang digunakan dalam aktivitas manusia terbuat dari plastik, sementara plastik sendiri merupakan bahan yang tidak mudah terurai di lingkungan, memerlukan waktu lama sampai puluhan tahun untuk dapat terdekomposisi.Masih sedikitnya partisipasi masyarakat terhadap pengelolaan sampah yang berwawasan lingkungan menunjukkan sangat diperlukannya usaha yang intensif dan berkesinambungan untuk meningkatkan partisipasi masyarakat terhadap pengelolaan sampah di lingkungannya secara mandiri. Partisipasi publik merupakan kunci keberhasilan untuk mewujudkan kota yang bersih, hijau dan teduh sekaligus meraih Adipura dan menghilangkan citra kota terkotor se-Indonesia.

Banyak hal yang bisa dilakukan disana terutama kegiatan edukasi dan pengembangan softskill para pengurus ataupun pemuda Karang Taruna

Mereka mengajak para anak-anak muda yang peduli dengan desa untuk ikut proyek pendidikan dan sosial ke masyarakatan. Dan membuka kegiatan yang bersifat pengabdian kepada masyarakat untuk dilaksanakan disana.

Proses daur ulang sampah plastik dimulai dengan membersihkan bungkus plastik dari sisa isi yang masih tersisa. Kemudian dipilih bagian yang ingin dijadikan sebagai motifnya. Gunting bagian tepi atas dan bawah. Kemudian lipat bagian atas dan bawah ke arah dalam dengan lebar sekitar $2 \mathrm{~cm}$.

Setelah lipatan plastik terkumpul cukup banyak, anyam lipatan-lipatan tersebut sesuai bentuk yang diingankan (misalnya, tas). Kemudian anyaman yang sudah selesai dianyam, bagian dalamnya diberi kain sebagai pelapis. Satukan anyaman dan kain dengan cara dijahit, beri ritsleting dan tali sebagai pegangan tas.

Taman Belajar Kreatif Mekarsari memiliki kesempatan untuk berperan penting dalam mengembangkan generasi muda khususnya dalam bidang sosial, namun masih memerlukan masukan-masukan berupa pelatihan untuk memperkaya pemahaman mereka demi menciptakan program-program belajar yang lebih baik. 
BAKTIMAS

Jurnal Pengabdian pada Masyarakat
Vol. 2, No. 1,

Maret 2020
eISSN 2685-113x

pISSN 2685-0303

\section{PENUTUP}

Acara kegiatan pengabdian kepada masyarakat ini dilaksanakan selama 3 hari, yaitu sebagai berikut.Pertama, pembukaan oleh Ketua Pengurus Taman Belajar Kreatif Mekar Sari kemudian dilanjutkan laporan dari Ketua Kegiatan sekaligus penjelasan pelatihan dan pembagian bahan praktek dan contoh model produk.Selanjutnya yaitu pemberian motivasi berwirausaha oleh narasumber.Kedua, kegiatan demonstrasi pembuatan produk usaha berbahan dasar sampah plastik.Ketiga yaitu kegiatan penyuluhan mengenai bagaimana hasil produk tersebut dibuat sebagai kegiatan wirausaha.

\section{DAFTAR PUSTAKA}

Kementerian Pekerjaan Umum. (2010). Modul Pengolahan Sampah Berbasis 3R. Badan Penelitian Dan Pengembangan - Pusat Penelitian Dan Pengembangan Permukiman.

Nasution, S. R., Rahmalina, D., Sulaksono, B., \& Doaly, C. O. (2019). IbM: PEMANFAATAN LIMBAH PLASTIK SEBAGAI KERAJINAN TANGAN DI KELURAHAN SRENGSENG SAWAH JAGAKARSA JAKARTA SELATAN. Jurnal Ilmiah Teknik Industri. https://doi.org/10.24912/jitiuntar.v6i2.4119

Purwaningrum. (2016a). Upaya Mengurangi Timbulan Sampah Plastik. Jurnal Teknik Lingkungan.

Purwaningrum, P. (2016b). UPAYA MENGURANGI TIMBULAN SAMPAH PLASTIK DI LINGKUNGAN. INDONESIAN JOURNAL OF URBAN AND ENVIRONMENTAL TECHNOLOGY. https://doi.org/10.25105/urbanenvirotech.v8i2.1421

Purwanto, I., Fatimah, D. D. S., \& Partono, P. (2013). Perancangan Sistem Informasi Transaksi Tabungan Bank Sampah Garut. Jurnal Algoritma. https://doi.org/10.33364/algoritma/v.9-2.254

Qodriyatun, S. N. (2018). Sampah Plastik: Dampaknya Terhadap Pariwisata dan Solusi. Info Singkat, Pusat Penelitian Badan Keahlian DPR RI.

Sulistiyorini, N. R. S., Darwis, R. S., \& Gutama, A. S. (2016). PARTISIPASI MASYARAKAT DALAM PENGELOLAAN SAMPAH DI LINGKUNGAN MARGALUYU KELURAHAN CICURUG. Prosiding Penelitian Dan Pengabdian Kepada Masyarakat. https://doi.org/10.24198/jppm.v3i3.13786 